\title{
Women [Re]Build: Stories, Polemics, Futures
}

Women [Re]Build:

Stories, Polemics, Futures

By Franca Trubiano,

Ramona Adlakha,

and Ramune Bartuskaite (eds.)

Novato CA, USA: Applied Research and Design

/ Oro Editions, 2019, 2018

$241 \mathrm{~mm} \times 165 \mathrm{~mm}$

144 pages

US\$ 29.95 (paperback)

ISBN: 978-1-943532-43-8

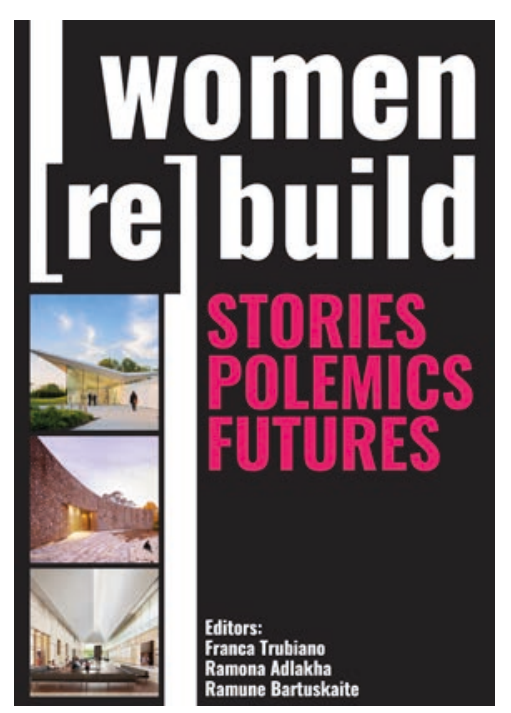

One of the strengths of the small but ambitious volume Women [Re]Build:

Stories, Polemics, Futures (Franca Trubiano, Ramona Adlakha, Ramune Bartuskaite, eds.) is its refusal to presume singular or definitive answers to its clear central question. As framed by Franca Trubiano in her thorough overview article, that question is direct: "How will we know when and if women have [re] built architecture?" The book's contributors, which include several generations of architectural educators, scholars, and practitioners, each volunteers her own metrics, each metric in alignment with her specific framing of the issues at stake. The result is a compilation that speaks to problems inherent to architecture, both generally and for its female practitioners, and to the cultural moment of which the book is part. 
Derived from two architecture student-organized conferences on women in architecture at the University of Pennsylvania in 2017 and 2018, the book draws upon a broad spectrum of narrative forms: interviews, position pieces, quantitative analytics, reports from the field, and autobiographical accounts. Beginning with editorial statements and a brief but pointed introduction by Joan Ockman on architecture and the \#Metoo movement that dominated the news in 2017, the book is subdivided into three sections interleaved with four interviews, each with a female practitioner. The first section offers an attempt at definitions, historical context, and cautionary tales. The second section tracks two mid-career architects whose work in academia and practice deploys architecture as a tool through which to influence public policy governing spatial equity. This section also includes the American Institute of Architecture's sobering attempt to quantify the number and status of female practitioners in the US over time. The final section consists of first-person testimonials by three women at different stages of more traditional architectural practice, one in small collaborative practice, another in corporate practice managing the construction of large flagship projects, and the third, the principle of an international boutique office.

What each author shares with the others is some degree of ambivalence about how to use "woman," whether as a noun, an adjective, or a construct to be challenged. In some cases, all of these usages coexist in a single article as the author sometimes moves unaware amongst them. The editors, to their credit, try to allow room for everything but by ensuring that all authors and interviewees are women, they presume the usage of "woman" as an all-inclusive noun. As quickly becomes clear, however, "women" as a general proxy edges towards precisely the kinds of generalization that the authors are at pains to avoid. "Admittedly, women have sometimes enabled their own disappearance," writes Despina Stratigakos, "Male architects do not hesitate to take an active role... Women - taught that self-promotion is an unattractive female trait - have made less effort to tell their stories." ${ }^{1}$ All women? Some women? At what moment in history? And what place do such generalizations have in the twenty-first century? Without a metric or a qualifier, this desire for an all-inclusive category runs counter to the book's central ambition. Mary McLeod's subtle history of women architects is more careful. McLeod's brief but deep historiography includes not only unsung female reformists of the nineteenth- and early-twentieth-century domestic sphere but also the rethinking of practice in the 1960s and 1970s by women whose training includes them in a more narrowly defined discipline of architecture. Most memorable, however, is an anecdote she shares from an interview she completed for her monograph on Charlotte Perriand. She recalls that Perriand was angered by an interpretation, originated by Beatriz Colomina but in the meantime near-canonical, of a famous photograph of her on the tubular chaise she co-authored with Le Corbusier. Perriand was "angered" by the implication that the photograph evidenced her relegation to a 
lesser role simply because she faced away from the camera. ${ }^{2}$ Instead, she insisted on the fact that she had staged the photo, her face diverted to draw attention to the furniture design rather than the person lounging on it. McLeod raises this anecdote to the status of a cautionary tale: we simplistically tend "to see women architects as victims." ${ }^{3}$ Instead, she argues, those who wish to measure the changing role of women in architecture should "raise questions about how we characterize feminism and feminist thought...to assess them in terms of their own social and political context."

The use of "woman" as an adjective is, as several authors argue, similarly fraught. Stratigakos' article, detailing her efforts to have women who practice in the field of architecture increasingly represented on Wikipedia, references the dangers of calling out gender in classifications: that the use of "woman" or "female" as a qualifying adjective has often become a way to ghettoize women practitioners, not only in architecture but in any discipline. Wikipedia lists dedicated, for instance, to American women novelists, she points out, led to Joyce Carol Oates' removal from the more general and oft-searched list of American novelists, and to the disappearance of Maya Angelou from the mainstream of American writing. Parity, she seems to argue, is best served when women practitioners stand next to their male colleagues. The book offers a counterargument, though, in lla Berman's essay "Beyond Equality." Drawing heavily on a broad spectrum of Feminist, Queer, and Diaspora theory, she argues instead that the problem lies in women's (again, that broad and ill-defined noun-as-proxy) internalization of "the mythical norms to which we have so readily assimilated." ${ }^{4}$ Equity, Berman explains, is simply another flavor of subjugation to the constructs favoring "testosterone-infused bodies." ${ }^{5}$ Women should reinvent structures by which success is measured, rather than accommodating them, in a model referencing the Black Lives Matter movement. Perhaps. In the end, is it all - to return to Trubiano's framing question - a matter of determining the yardstick by which success is measured?

Most interesting and perhaps difficult is the question of how "woman architect" is constructed. Do women in architecture have an inherent social bent? The selections in the book's second section might imply so. Lori Brown's work on the buffer zones and spaces of abortion clinics directly addresses spatial issues unique to cisgendered women. Julie Torres Moskovitz's analysis of New York City Loft Law argues for a specific kind of housing equity in a gentrifying city. But does this mean that women practice differently, distinctly? Here, the book's answer seems to be: no, not necessarily. To their credit, the two anonymous interviewers in the well-edited interviews with Marion Weiss (Weiss Manfredi) and Billie Tsien (TWBT Architects) don't press the issue. They pursue instead a line of questioning that can establish the scaffolding, from education to early practice to success, upon which two thoughtful women have built their careers. This approach maps the career thresholds identified in the 
AIA Equity by Design (ExD) survey, explained by Annelise Pitts in her essay. Perhaps unsurprisingly, the factors cited by female respondents for departing a conventional architecture career were "low pay, long hours and lack of advancement opportunities." ${ }^{6}$ Translated into charts, the findings track such pressures as childcare provision and comparable pay over time by gender. They also allow for a broader definition of architectural practice, a response to the insight that in many ways, architecture is "a field that wasn't serving anyone particularly well." " A quick glance at the salary chart, which tops out just below $\$ 140,000$ after thirty years of practice, speaks volumes. Without the cost of living or materials, a typical three-year US architecture master's degree will cost $\$ 150,000$. The financial prospects are dire. Are women less likely than men to remain in an underpaid profession over time? The US economy has, in the past fifty years, quickly come to terms with the entry of women into the workforce. A 2011 WSJ/McKinsey study estimates that the presence of women in the economy since the 1970 s accounts for more than a quarter of total GDP growth, yet household buying power has stagnated. Under these conditions, should women be applauded for leaving a profession that demands so much and remunerates so poorly? Perhaps it is their male counterparts who are trapped in a cycle of undervaluation.

Nicole Dosso's sharp, personal observations on her experience as a junior employee overseeing construction on SOM's 7 World Trade Center Tower appear near the book's end. On one occasion abandoned by the elevator operator on the tower's unsheathed upper floors, locked into a fire stair still under construction, reliant upon the goodwill of two construction workers on a cigarette break, she prevails. With both appreciation and critical awareness, she quotes Nathaniel Owings' comments on Natalie de Blois, SOM's pioneering partner from the 1950s onwards. In these cases and others, her essay reflects on many of the book's themes: history, metrics, and a sense of purpose structure her reflections. She offers no general answers, but her approach does offer evidence of just how much competence, wit, and tenacity are required to realize buildings in the contemporary fiscal and regulatory climate. Perhaps these are the metrics best used to answer Trubiano's question after all.

\section{Notes}

1. Franca Trubiano, Ramona Adlakha, and Ramune Bartuskaite eds., Women [Re]Build: Stories, Polemics, Futures (Novato CA, USA: Applied Research and Design / Oro Editions, 2019), 52.

2. Ibid., 47.

3. Ibid., 48.

4. Ibid., 35.

5. Ibid., 36.

6. Ibid., 87.

7. Ibid., 86. 
Lynnette Widder is an Associate Professor of Practice in the Master of Sustainability Management program at the Earth Institute, Columbia University. Prior to joining the Earth Institute, she was an Associate Professor and Architecture Department Head at the Rhode Island School of Design; she has also taught at the ETH Zurich, Cornell University, City College of New York, and Cranbrook Academy. She is the co-author of two books: Ira Rakatansky: As Modern as Tomorrow (2010) and Live Projects: Pedagogy into Practice (2014). She has curated various exhibitions and her articles on architectural history and sustainable building have appeared in many international magazines and journals. From 1994 to 1998, she was also the Editor of Daidalos. Her professional work with "aardvarchitecture" has been published in the US, Europe, China, and Australia. Widder holds a Sc.D. from the ETH Zurich (2016) and an M.Arch. from Columbia University (1990). E-mail: Iw268@columbia.edu 